\title{
Use of vital wheat gluten in aquaculture feeds
}

\author{
Emmanuelle Apper-Bossard, Aurélien Feneuil, Anne Wagner and Frédérique Respondek
}

\begin{abstract}
Summary
In aquaculture, when alternative protein sources of Fish Meal (FM) in diets are investigated, Plant Proteins (PP) can be used. Among them, Vital Wheat Gluten (VWG) is a proteinaceous material obtained from wheat after starch extraction. "It is mainly composed of two types of proteins, gliadins and glutenins, which confer specific visco-elasticity that's to say ability to form a network providing suitable binding. This will lead to specific technological properties that are notably relevant to extruded feeds". Besides these properties, WWG is a high-protein ingredient with an interesting amino-acid profile. Whereas it is rather low in lysine, it contains more sulfur amino acids than other PP sources and it is high in glutamine, which is known to improve gut health and modulate immunity. WWG is a protein source with one of the highest nitrogen digestibility due to a lack of protease inhibitor activity and to the lenient process used to make the product. By this way, addition of VWG in diet does not adversely affect growth performance in many fish species, even at a high level, and may secure high PP level diets that can induce health damages.
\end{abstract}

Keywords: Vital wheat gluten, Fish, Protein, Digestibility, Performance, Health

\section{Introduction}

Intensive production of farmed fish, fed with compound feeds, has been largely increased mainly due to the growth of aquaculture production, but also because it is the most efficient way of production [1]. In such feeds, Fish Meal (FM) used to be the major source of proteins, especially for marine fish and salmonids [2]. Nevertheless, because of the limited amount of available FM in the market, its lack of sustainability, and its increasing price, its inclusion in diets has been progressively reduced. In order to achieve a low FM incorporation (below 10\%) without impairing growth performance, an active research was conducted on plant proteins (PP), which represent an interesting alternative to FM. In this context, many studies were undertaken to evaluate the effects of replacing FM by different types of PP on fish growth and health [3-5]. Nowadays, several studies are exploring the possibility to decrease FM in a large extent by replacing them with a mixture of several PP [6].

Among the tested PP being considered to replace FM, Vital Wheat Gluten (VWG) is a PP source that has been given very promising results. Indeed, VWG can act as a pellet binder in extruded feed. Furthermore, it is a high quality protein source, highly digestible, with an interesting profile of amino-acids, especially a high level of

\footnotetext{
* Correspondence: Emmanuelle.apper-bossard@tereos.com

Tereos Syral, Z.I. Portuaire, 67 390, Marckolsheim, France
}

glutamine. The action of antinutritional substances was not observed when

wheat gluten was used as fish meal replacement [7]. As a result, growth performance and feed efficiency are not modified when up to $50 \%$ of FM are replaced with VWG in the diet of salmon [8], trout [9], and sea bream [10]. Furthermore, when compared with soybean-meal (SBM), VWG does not damage gut structure in Atlantic salmon [8]. The use of VWG has to be emphasised in a global context tending to decrease incorporation of FM. Thus, this paper aims at reviewing the use of VWG, its functionalities and properties regarding farmed fish.

Vital wheat gluten: technological and nutritional properties VWG can be defined as "a cohesive, visco-elastic, proteinaceous material prepared as a co-product of the isolation of starch from wheat flour" [11]. It is obtained from wheat flour by washing the dough preparation under water, and then centrifugation. This process removes soluble fibres and starch fractions and recovers the insoluble protein fraction that is mainly constituted of two fractions defined as follows according to their solubility in aqueous alcohols: soluble gliadins and insoluble glutenins [12], which are balanced with equal amounts.

Gliadins, which are monomeric proteins (intrachain disulfide bonds) with relatively low molecular weight (30 to $100 \mathrm{kDa}$ ), contribute to dough viscosity and extensibility, 
whereas glutenins, which are polymeric proteins (intraand interchain disulfide bonds) with high molecular weight (100 kDa to more than $10,000 \mathrm{kDa}$ ), are both cohesive and elastic, being responsible for tenacity (resistance to deformation) and elasticity (Figure 1). Gliadins can be qualified as plasticiser for glutenins.

\section{A pellet binder}

Due to its visco-elasticity, VWG can act as a pellet binder in extruded fish feed to partially replace starch or indigestible binders [8]. Indeed, the ability of fish to hydrolyse starch in the intestine and to regulate blood glucose concentration when the digestible carbohydrate level is high varies among species and is generally rather low [13], related to the enzymatic digestive capacity [14]. For example, the Atlantic salmon capacity to hydrolyse starch is low. Furthermore, administering glucose results in persistent hyperglycaemia in rainbow trout, common carp, red sea bream, yellowtail, and catfish [13], suggesting these species are not able to regulate glycaemia when fed with high level of digestible carbohydrates. That is why the starch amount is generally kept low in diets for fish, limiting its use as a technological binder.

Upon hydration, mixing, shearing, and heating (effects induced by the feed preparation, which is mostly done by extrusion-cooking), gliadins and glutenins interact in the dough through forces of various natures linked to their compositions: non-covalent bonds (hydrogen, ionic, and hydrophobic bonds) and covalent disulfide bonds [12] (Figure 1). Thus, gluten forms a strong cohesive network to entrap the other ingredients, providing adapted physical characteristics to the pellet in term of binding: improvement of the pellet hardness and pellet durability index (properties defined in Sorensen 2012). On our pilot extrusion line (Application Centre Tereos Syral, Marckolsheim, France), the production of two different salmon formulations containing 10 or $20 \%$ VWG (replacement of Soy Protein Concentrate (SPC) with VWG to switch from one formulation to the other) emphasised the importance of this trend: hardness and pellet durability index increase from $35 \mathrm{~N}$ to $48 \mathrm{~N}$ and from $97 \%$ to $98 \%$, respectively, with increasing VWG. Similarly, a higher breaking force was induced by incorporating VWG compared to fish meal and SPC [15]. Moreover, VWG water insolubility reduces pellet breakdown [11], which can be interesting in cases where water stability must be high: for shrimp feeds (long residence time in water before eating) and in farms transporting the pellets from the weighing cell to the fish cages with water.

\section{A protein and amino acid source}

The protein/energy ratio recommendation is higher for fish diets than for terrestrial vertebrates like pigs or poultry. Indeed, their basal energy requirements are lower than those of terrestrial vertebrates, due to the aquatic mode of life, poikilothermy, and ammonotelism [16]. As a result, the relative proportion of dietary protein in fish feed is higher than in terrestrial vertebrate feed. Dietary protein is then the major component of formulated fish feed. It is necessary to get both ingredients high in Crude Protein (CP) and high-quality proteins. Besides its technological properties, VWG has interesting nutritional values for fish feeds and is high in CP. The CP content is $80 \%$, which is higher than in FM, SPC, Soybean Meal (SBM) or Pea Protein Concentrate (PeaPC) in which it represents between 44 and $72 \%$ [17].

Regarding Essential Amino Acids (EAA), VWG is rather low in lysine, tryptophan, and arginine (Figure 2). Thus, a dietary supplementation with lysine in fish feed high in VWG is necessary. As example, while body of salmon contains $9.3 \mathrm{~g}$ lysine/100 g CP, VWG contains only 1.5 to $1.7 \mathrm{~g} / 100 \mathrm{~g}$ CP [18]. Several experiments showed VWG can successfully replace a large part of FM when diets are supplemented with free lysine in salmonids $[19,20]$. A dose-effect relationship study involving VWG and lysine in rainbow trout showed better growth performance was obtained when FM was replaced with up to 50\% VWG and when $0.29 \%$ to $0.58 \%$ lysine was added [20].

Beside the low amount of lysine, VWG contains a relatively high concentration of sulfur-containing amino acids,

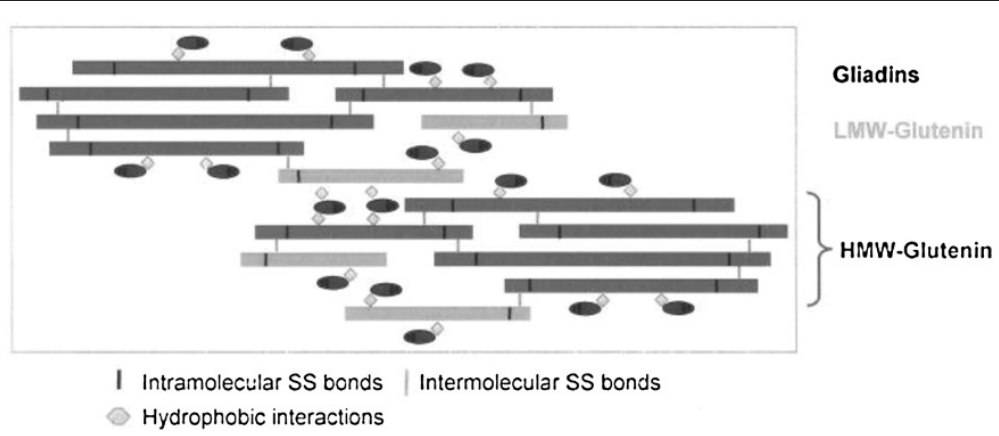

Figure 1 Representation of the gluten visco-elastic network and the place occupied by the gliadin and glutenin fractions within its structure. 


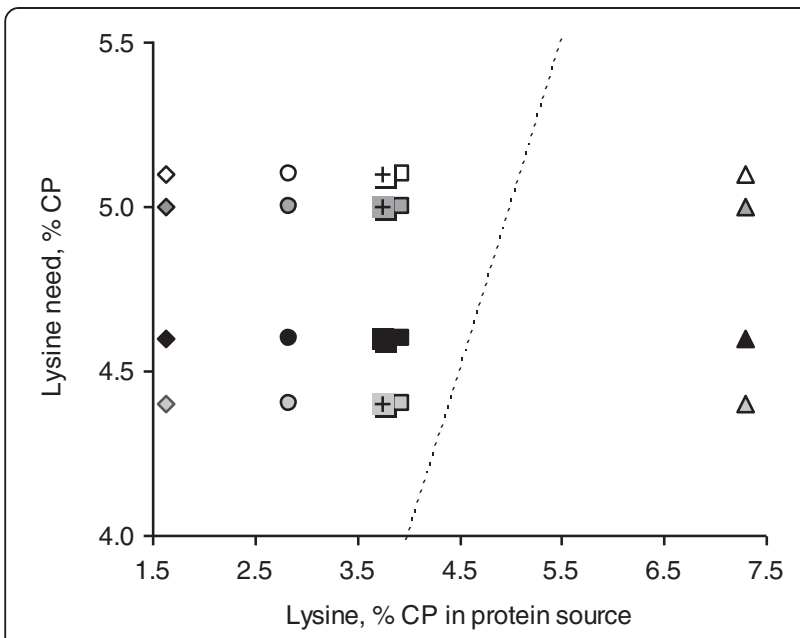

Figure 2 Lysine requirements of several species of fish compared to content in different protein sources expressed as $\%$ of Crude Protein (CP). White symbols: Nile tilapia requirement; dark grey symbols: Atlantic salmon requirement; black symbols: shrimp requirement; light grey symbols: European sea bass requirement. $\diamond$ : Vital Wheat Gluten; ०: Soybean Meal; +: Pea Protein Concentrate; $\square$ : Soy Protein Concentrate; $\Delta$ : Fish Meal. Dotted line: requirement of fish $=$ content in protein source.

due to the numerous di-sulfur bounds $(1.8 \%$ CP of methionine and $2.6 \%$ CP of cysteine), whereas PP sources are generally low in sulfur-containing amino acids (Figure 3). As examples, SBM and SPC respectively contain 1.4 and $1.3 \mathrm{~g} /$ $100 \mathrm{~g}$ CP of methionine and 1.3 and $1.4 \mathrm{~g} / 100 \mathrm{~g}$ CP of cysteine, which is lower than fish requirements. Furthermore,

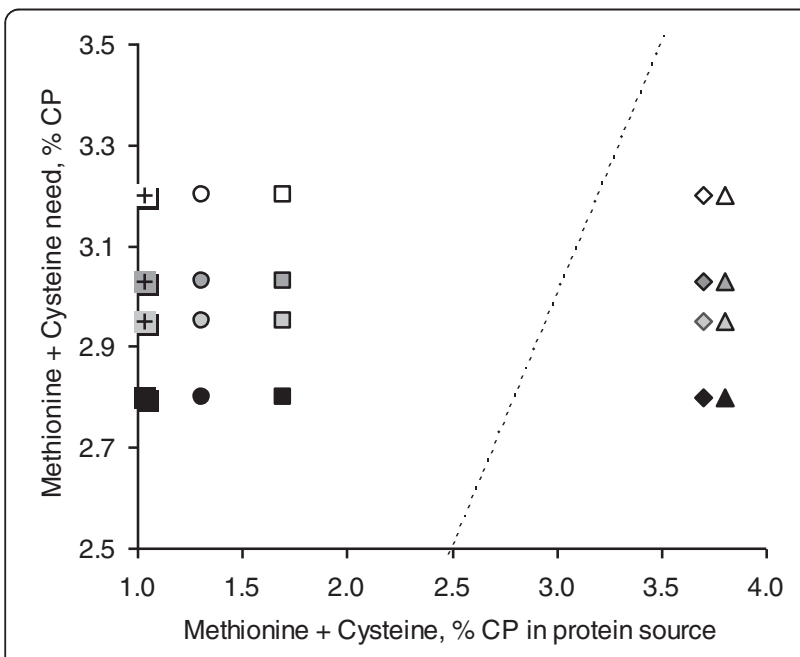

Figure 3 Sulfur amino-acid requirements of several species of fish compared to content in different protein sources, expressed as \% of Crude Protein (CP). White symbols: Nile tilapia requirement; dark grey symbols: Atlantic salmon requirement; black symbols: Asian sea bass requirement; light grey symbols: European sea bass requirement. $\diamond$ : Vital Wheat Gluten; o: Soybean Meal; +: Pea Protein Concentrate; $\square$ : Soy Protein Concentrate; $\triangle$ : Fish Meal. Dotted line: requirement of fish $=$ content in protein source.
VWG is high in leucine, with about $7.9 \mathrm{~g} / 100 \mathrm{~g}$ CP. Leucine is considered as the main amino acid triggering muscle protein synthesis and inhibiting proteolysis in mammals [21]. In particular, leucine can stimulate the PI3K-Akt-TOR pathway [22]. This mechanism may also occur in fish. Indeed, it is shown that in different species, amino acids regulate TOR signalling pathway [23]. Furthermore, supplementing media containing $0.6 \mathrm{mM}$ leucine with an additional $2.5 \mathrm{mM}$ leucine reduced rates of protein degradation of rainbow trout primary myocytes by $8 \%$ [24].

Regarding non-essential amino acids, VWG is high in glutamine: from 35 to $40 \%$ CP. Glutamine is a major substrate for all rapidly proliferating cells and plays an important role in maintaining intestinal trophicity [25] (Table 1). Also, glutamine is one of the most important energy substrate of enterocytes. Several studies recently demonstrated free glutamine significantly increases enterocyte and microvilli length of catfish gut [26], hybrid striped bass [27], and juvenile hybrid sturgeon [28] (Table 1). Besides these effects on gut morphology, glutamine also constitutes a major substrate for immune cells, thus modulating immune response [25] (Table 1). The serum non-specific immunity of juvenile hybrid sturgeon is modulated whereas lysozyme activity is increased in hybrid striped bass by adding glutamine in diets $[27,29]$. Moreover, glutamine also plays a role in eliminating free radicals as it acts as a precursor for the glutathione synthesis [30]. Such effects are reported for juvenile hybrid sturgeon [29] and hybrid striped bass [27]. Glutamine has proven to stimulate muscle synthesis in terrestrial vertebrates [31], but such results are not available for fish. However, dietary glutamine supplementation increases growth performance in juvenile hybrid sturgeon fed with a SPC-based diet [28], and in hybrid striped bass fed with a FM and SBM-based diet [27] (Table 1). Nevertheless, to our knowledge, the effects of VWG on immune response or on antioxidant status, compared to other PP sources, have not been investigated whereas its high amount of glutamine should be explored.

\section{Wheat gluten in diets of fish Highly digestible}

VWG is a highly digestible protein source for several species (Table 2). Apparent digestibility of $99 \%$ for CP when feeding a diet with $92.7 \%$ CP from VWG and 1.45\% lysine is obtained in rainbow trout [33], whereas the apparent CP digestibility of VWG was estimated to approximate $100 \%$ [34]. In shrimp (Litopenaeus vannamei), the apparent CP digestibility is estimated at 98\% [35], whereas it is $100 \%$ in Nile tilapia [17]. The apparent CP digestibility of VWG is higher than the apparent CP digestibility of numerous protein sources derived from plants and animals (Table 2). An inclusion of 15\% VWG in a FM-based diet results in increasing $\mathrm{CP}$ digestibility in juvenile Nile tilapia. The same result is observed when around 30\% VWG 
Table 1 Effects of adding glutamine on growth performance, gut structure and activity, and immune parameters in different species of fish

\begin{tabular}{lll}
\hline Species & $\begin{array}{l}\text { Physiologic } \\
\text { status }\end{array}$ & $\begin{array}{l}\text { Trial } \\
\text { period (d) }\end{array}$ \\
\hline jian carp Cyprinus carpio & Juvenile $\mathrm{iBW}^{1}=$ & 80
\end{tabular}

Proteins in diets

Glutamine

Main results

Reference

Juvenile iBW ${ }^{1}=80 \quad 35 \% \mathrm{FM}^{2} ; 20.5 \%$ Rice Gluten Meal;

$C P^{3}=33 \%$ Substitution of glycine by Gln

(Gln\% in diet)

[32]

Percent weight gain, feed efficiency, and productive protein linearly increase until 1.2\% and reach a plateau afterwards.

Gut morphology and activity

Intestine fold height, and gut

length and weight linearly increase until $1.2 \%$ and reach a plateau afterwards.

Protease, lipase, AKP, and Na,K-ATPase activities linearly increase until $1.2 \%$ and reach a plateau afterwards in the 3 segments of gut.

Hybrid sturgeon Acipencer Juvenile iBW = 56 schrenckii $\times$ Huso dauricus $22.38 \mathrm{~g}$
20\% SBM²; 10\% Blood Meal; 20\% FM; $8 \%$ Corn Protein; $\mathrm{CP}=44.8 \%$ Substitution of $\mathrm{SPC}^{2}$ by $\mathrm{HWG}^{2}(0$ to $5 \%)$ or by Aln-Gln (1\%)

$0.63^{*} 0,0.3,0.6,0.9, \quad$ Performance

Relative Growth Rate and feed efficiency linearly increase from 0 to $1.2 \%$ of Gln in HWG and increase with free Gln. Gut morphology and activity

Intestine fold height, and gut length and weight linearly increase from 0 to $1.2 \%$ of Gln in HWG and increase with free Gln. Protease, amylase, lipase, and Na,K-ATPase activities linearly increase until 1.2\% of Gln in HWG and increase with free Gln in the 3 segments of gut

Immune response and antioxidant status

Glutathione peroxydase, glutataione, and superoxide dismutase concentrations linearly increase whereas malondialdehyde concentrations decrease until 1.2\% Gln in HWG and with free $\mathrm{Gln}$ in intestine, hepatopancreas, and muscle.

Modulation of serum non-specific immune parameters according to a quadratic response with 0 to $1.5 \%$ Gln in HWG. Linearly increase of serum concentrations of $\mathrm{C} 3$ and $\mathrm{C} 4$ with addition of free Gln.

Performance

Specific Growth Rate and feed efficiency increase with 1\% of Gln, not with $2 \%$.

Gut morphology

No change in pyloric caeca. Enterocyte and microvillus heights in distal intestine and fold length in the proximal intestine increase with Gln. Immune response Higher serum lysozym activity with $1 \% \mathrm{GIn}$. Increased extracellular superoxide anion production with $1 \%$ and $2 \% \mathrm{Gln}$. 
Table 1 Effects of adding glutamine on growth performance, gut structure and activity, and immune parameters in different species of fish (Continued)

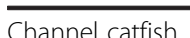

Ictalurus punctatus

Juvenile iBW $=70$

$13.4 \%$ casein; $3.76 \%$ gelatine; $7.1 \%$ of

$0,0.5,1,1.5,2,3$

No significant effect on growth performance. Increase of lipids in carcasses with 2 and $3 \% \mathrm{Gln}$.

Gut morphology Mucosal fold length, enterocyte

height and microvilli height increase until $2 \%$

Gln in the 3 segments of intestine.

${ }^{1}$ iBW: initial Body Weight; ${ }^{2}$ FM: Fish Meal, SBM: Soybean Meal, SPC: Soy Protein Concentrate, HWG: Hydrolysed Wheat Gluten ${ }^{3}$ CP: Crude Protein.

*Inclusion of $1 \%$ Aln-Gln; **: inclusion of 0 to $5 \%$ Hydrolysed wheat gluten. 
Table 2 Apparent digestibility coefficient (ADC) of crude protein (CP) of diets with different protein sources depending on the inclusion rate and the species

\begin{tabular}{|c|c|c|c|c|c|}
\hline Species & Physiological status & Protein source $^{1}$ & Protein source in diet (\%) & $\begin{array}{l}\text { ADC of CP in diet or } \\
\text { of ingredient (\%) }\end{array}$ & Reference \\
\hline \multirow[t]{10}{*}{ Coho salmon } & Growing & WWG & $30^{2}$ & 98.4 & {$[34]$} \\
\hline & & SBM & 100 & 96.4 & \\
\hline & & Herring FM & & 96.6 & \\
\hline & & Deboned meal & & 96.7 & \\
\hline & & CGM & & 95.2 & \\
\hline & & WWG & & 99.6 & \\
\hline & & SBM & & 93.0 & \\
\hline & & Herring FM & & 94.7 & \\
\hline & & Deboned meal & & 95.1 & \\
\hline & & CGM & & 91.9 & \\
\hline \multirow[t]{10}{*}{ Rainbow trout } & Growing & WWG & $30^{2}$ & 98.6 & [34] \\
\hline & & SBM & 100 & 95.5 & \\
\hline & & Herring FM & & 96.6 & \\
\hline & & Deboned meal & & 97.2 & \\
\hline & & CGM & & 97.4 & \\
\hline & & WWG & & 100 & \\
\hline & & SBM & & 90.1 & \\
\hline & & Herring FM & & 94.6 & \\
\hline & & Deboned meal & & 96.7 & \\
\hline & & CGM & & 97.3 & \\
\hline \multirow[t]{5}{*}{ Australian silver perch } & Juvenile & WWG & 29.7 & 99.8 & {$[37]$} \\
\hline & & SBM & & 94.8 & \\
\hline & & Australian FM & & 92.3 & \\
\hline & & SDBM & & 90.2 & \\
\hline & & CGM & & 95.4 & \\
\hline \multirow[t]{4}{*}{ Gilthead sea bream } & Growing & WWG & $100^{3}$ & 96 & {$[39]$} \\
\hline & & SPC & & 92 & \\
\hline & & FM & & 86 & \\
\hline & & CGM & & 90 & \\
\hline \multirow[t]{4}{*}{ Nile tilapia } & Juvenile & VWG & 15 & 92.6 & [40] \\
\hline & & SBM & & 90.5 & \\
\hline & & DWD & & 88.9 & \\
\hline & & FM & & 89.7 & \\
\hline \multirow[t]{6}{*}{ Atlantic cod } & Juvenile & WWG & 29.8 & 99.9 & [36] \\
\hline & & SBM & & 92.3 & \\
\hline & & SPC & & 98.6 & \\
\hline & & PeaPC & & 89.8 & \\
\hline & & CGM & & 86.3 & \\
\hline & & Herring FM & & 93.3 & \\
\hline
\end{tabular}

'VWG: Vital Wheat Gluten; SBM: Soybean Meal; CGM: Corn Gluten Meal; SDBM: Spray-Dried Blood Plasma; SPC: Soy Protein Concentrate; PeaPC: Pea Protein Concentrate; FM: Fish Meal.

${ }^{2}$ Digestibility coefficients are given for both the diet with $30 \%$ protein source and for each protein source.

${ }^{3}$ Digestibility coefficients are indicated for each protein source. 
are added in a herring FM-based diet in Atlantic cod [36] or Australian silver perch [37] (Table 2). In salmonids, the apparent CP digestibility of diets rises with increasing inclusion rate of VWG $[8,20,38]$, (Figure 4). In particular, in Atlantic salmon, the Apparent Digestibility (AD) of CP linearly increases from $88.6 \%$ with a FM-based diet to 93.6\% when including 50\% CP as VWG, and by extrapolating these results it was 100\% with 100\% CP from VWG [8].

In these species, the apparent availability of EAA is also very high. In shrimp (Litopenaeus vannamei), the apparent availability of EAA from VWG is similar to or higher than the one of FM, except for lysine and cysteine. VWG has been reported to have equivalent or higher value with respect to apparent digestibility of protein and to apparent absorption of amino acids when compared to FM $[8,34]$. Specifically, the apparent digestibility of CP and apparent absorption of amino acids significantly increased with higher proportion of CP from VWG, except alanine and lysine [8] (Figure 5). The trend for a lower apparent absorption coefficient of lysine may be explained by a deviation between true and apparent lysine digestibility with increasing VWG, due to a relative higher excretion of endogenous lysine with high level of VWG.

The digestibility of energy from VWG is also higher than the digestibility of energy from FM in Atlantic salmon as well as in gilthead sea bream and Atlantic cod $[8,39]$. In contrast with these results, a decrease of energy and fat digestibility occurs when FM is replaced with SBM

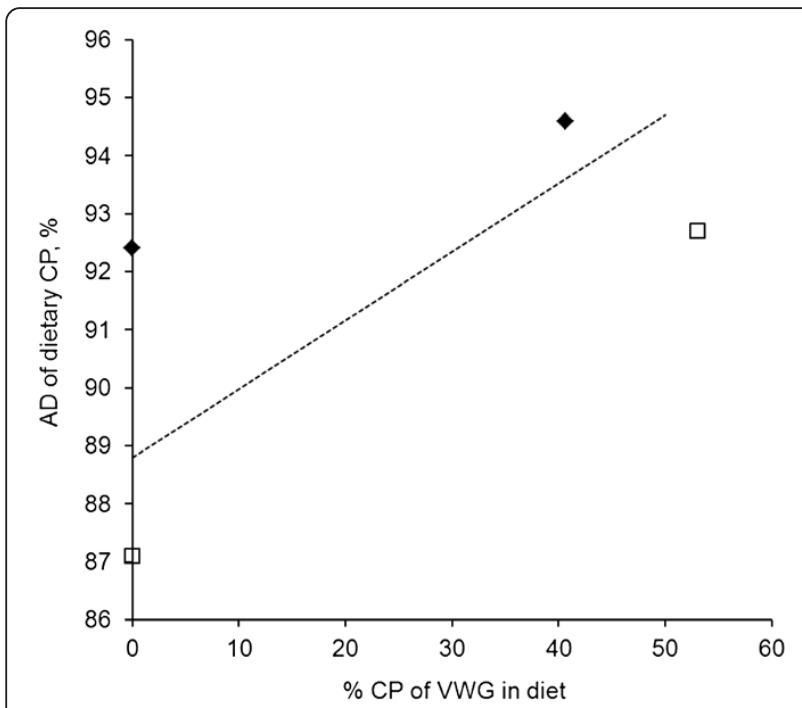

Figure 4 Evolution of Apparent Digestibility (AD) of dietary Crude Protein (CP) according to the inclusion rate of Vital Wheat Gluten in diet, expressed as\% of CP in Rainbow trout (adapted from [20]), European sea bass (adapted from [32]), and Atlantic salmon (adapted from [8]). : European sea bass; -_—: Atlantic salmon (linear regression: $A D_{C P}=88.8+0.118 \times G$, $G$ being protein from WWG expressed as\% of (P); $\square$ : Rainbow trout.

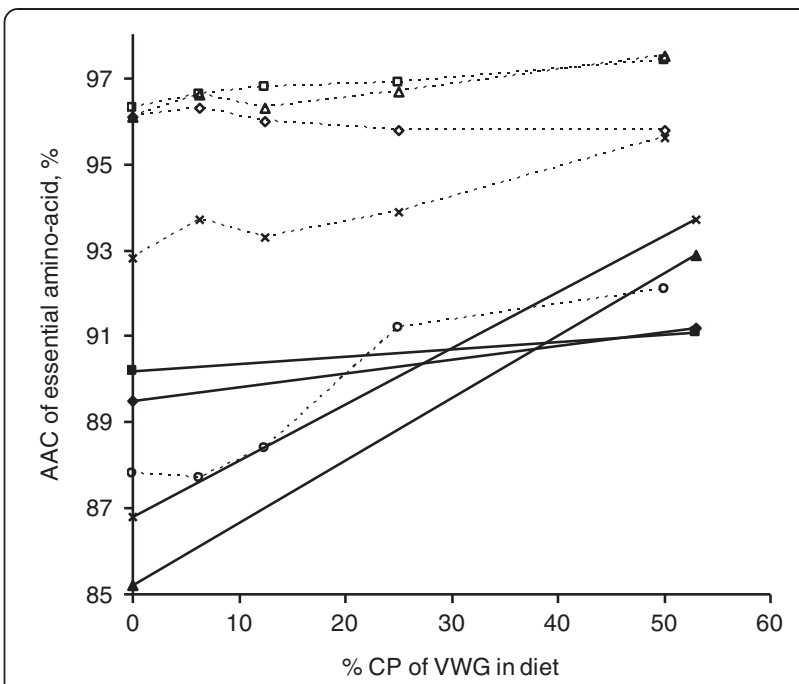

Figure 5 Evolution of Apparent Availability Coefficient (AAC) of Arginine, Leucine, Lysine, Methionine, and Tryptophan according to the inclusion rate of Vital Wheat Gluten in diet, expressed as \% of Crude Protein in Atlantic salmon (adapted from [8]) and Rainbow trout (diet supplemented with $0.29 \%$ Lysine; adapted from [20]). Dotted line: Atlantic salmon; solid line: Rainbow trout. $\square$ : Arginine; $\Delta$ : Leucine; $\diamond$ : Lysine; $\times$ : Methionine; $\circ$ : Tryptophan.

in Atlantic salmon [41] or by SPC and Corn Gluten Meal (CGM) in sea bream [39]. These differences may be attributed to a relative higher content of carbohydrates in soy protein ingredients or CGM compared to VWG. Carbohydrates are less available as an energy source to carnivorous fish for which the natural diet -and thus digestive metabolism- is based on lipids and proteins. VWG possesses both high gross energy and protein content and availability; it is then possible that a part of protein from VWG is used as an energy source in these species.

Phosphorus $(\mathrm{P})$ is an essential component of fish diets. Not only it affects hard tissues but also intermediary metabolism and in turn, feed conversion ratio. In the same time, as the aquaculture industry grows, there are concerns regarding $\mathrm{P}$ in effluents. Thus, it is important to formulate diets containing adequate $\mathrm{P}$ for fish growth and ensuring minimal level of $\mathrm{P}$ in effluent. $\mathrm{P}$ bioavailability in PP sources is widely variable because of the presence of ANF. P availability is higher in VWG than in FM, SBM, SPC, and CGM for rainbow trout and coho salmon [34]. The content of ANF, such as phytic acid, is a major factor restricting the use of SBM and SPC in diets of fish [8]. The major vegetable part of P (60 to 70\%) is bound to phytic acid, leading to a decrease in $\mathrm{P}$ availability in fish [42]. This phytic acid decreases the availability of cations such as zinc, magnesium, and calcium $[43,44]$ or protein [42]. This problem does not appear for VWG, in which P content is relatively low but is highly available because of the absence of phytic acid. 


\section{Low amount of fibres and no Antinutritional factors}

The replacement of FM with other PP sources may result in increasing the level of fibres in diets [45]. Shrimp and fish do not have a high capacity to digest dietary fibres, and a high dietary level of fibres reduces digestibility and utilisation of other nutrients, acting as antinutritional factors (ANF) in carnivorous, as well as in herbivorous species. For instance, the level of dietary fibres must be less than $10 \%$ in rainbow trout otherwise leading to decreased growth and dry matter digestibility [46]. In tilapia, reducing weight gain is observed when fed diets with $10 \%$ soluble as well as insoluble fibres compared to a control diet [47]. The negative effect of dietary fibres on digestibility of dry matter or $\mathrm{CP}$ and growth is also demonstrated in common carp [48], Atlantic salmon [49], or European sea bass [50]. Such results have not been described when adding VWG in fish feed. Compared to other PP sources, VWG does not contain a high level of fibres. The amount of fibres in VWG averages 0.5 to $1 \%$ and is comparable to the amount found in FM. It is more than 10-fold lower than the level of fibres in SPC or SBM that averages $4.5 \%$ and 7.0\%, respectively [17].

Additionally to increasing fibres, replacing FM by PP sources results in higher ANF content in diets. Such factors are defined as endogenous compounds of ingredients that may reduce feed intake, growth, nutrients digestibility and utilisation [51]. ANF are involved in the aetiology of diseases like enteritis, low lipid or protein digestibility and diarrhoea. These substances are numerous but the more relevant ones are phytic acids, enzyme inhibitors, lectin, saponins, phytoestrogens, phytosterols, and oligosaccharides. Due to their detrimental effects on zootechnical performance and nutrient utilisation, ANF must be taken into account when using high inclusion rates of PP for replacing FM [51].

The negative effects of ANF present in PP are different according to the type of PP, the process of production, and the dietary inclusion rate. Indeed, it appears that SBM induce histological and functional changes in gastro-intestinal tract (enteritis, increased susceptibility to bacterial infections, changes in absorptive cells ...) in salmonids [52,53]. Inconsistent results are described for PeaPC: they can induce enteritis in Atlantic salmon [54] whereas no change on digestibility and mineral availability of rainbow trout was observed when replacing $50 \%$ FM by PeaPC [54]. Several experiments testing SPC reported no change on growth when comparing to a control, even if some modifications of gut structure were noticed [54]. Compared to other PP sources, no action similar to ANF has been described when VWG was used as FM replacement in different species [7].

Finally, due to the absence of fibres and ANF combined with a high amount of glutamine, adding VWG in diets may represent an opportunity in the current context in which PP are more and more present in diets. Indeed, diets with less than 5-10\% FM are now formulated and used in practical diets for carnivorous fish. Such diets contain a mixture of several PP which have various nutritive properties. This strategy may lead to use complementary properties of different PP for balancing diets and diluting ANF.

\section{Growth performance}

Because of its high digestibility and its absence of actions typical of ANF, replacement of a large proportion of FM with VWG results in similar growth performance and fish composition whatever the species are (Table 3). In Rainbow trout, VWG successfully substitutes more than $50 \%$ FM providing diets are supplemented with lysine without affecting protein and lipid composition of the pooled carcasses $[9,20]$. Furthermore, another experiment shows the inclusion of $14.5 \%$ VWG in diets does not adversely affect the flavour of fillets [55]. In Atlantic salmon, the replacement of 35\% FM with VWG without supplementing by lysine results in similar final body weight and growth [8]. These authors estimate the replacement of FM with VWG without amino acid supplementation can go up to $50 \%$ based on the amount and the availability of lysine in VWG and on the requirement of fish. In European sea bass, substituting more than $50 \%$ FM with VWG in feeds does not impair palatability, growth performance, and nitrogen-energy retention [10]. In gilthead sea bream, the use of $88 \%$ CP from VWG not only replaced successfully FM but also produced better growth and feed conversion ratio, probably related to higher protein and energy intake of fish [39]. Such results are not obtained with CGM and SPC diets: feed efficiency and weight gain decrease when compared to FM (Table 4). In Nile tilapia fed with diets differing by their protein sources, the highest growth is reported for VWG, FM, and Soybean extract diet. In the same experiment, fish body composition is not significantly affected by diet ingredients [40] (Table 4). In shrimp, only few results are available but it seems the replacement of up to $20 \%$ marine protein with VWG does not modify feed efficiency [56].

\section{Health}

Even if the proportion of PP increases in fish feeds, and despite removing most of the indigestible carbohydrates, it still remains challenging when using plant protein concentrates at very high levels to replace up to $80 \%$ FM. Indeed, there are profound effects on metabolism, immunity, and gut health. In Rainbow trout and gilthead sea bream, protease activity is reduced with higher content of PP source until 100\% FM are replaced [57]. A total replacement of FM with a mixture of PP exerts a 
Table 3 Effects of replacement of fish meal (FM) with vital wheat gluten (VWG) on growth performance, N and P losses, and whole body composition of several species of fish

\begin{tabular}{|c|c|c|c|c|c|c|c|c|c|}
\hline Species & Duration (d.) & FM $\left(\% C P^{1}\right)$ & VWG (\%CP) & Other $\mathrm{PP}^{2}(\% \mathrm{CP})$ & $\mathrm{CP}$ in diet (\%) & Lys. Supp. (\% diet) & iBW (g) & Main results & Reference \\
\hline \multirow[t]{2}{*}{ Atlantic salmon } & \multirow[t]{2}{*}{126} & 100 & 0 & No & 41.3 & No & 952 & \multirow{2}{*}{$\begin{array}{l}\text { Similar growth - No modification in the mucosa } \\
\text { of the posterior intestine. }\end{array}$} & \multirow[t]{2}{*}{ [8] } \\
\hline & & 65 & 35 & No & 39.6 & No & 956 & & \\
\hline \multirow[t]{2}{*}{ Nile tilapia } & \multirow[t]{2}{*}{49} & 88 & 0 & No & 32.5 & No & 56.4 & \multirow{2}{*}{$\begin{array}{l}\text { Similar growth with WWG as with FM. Higher } \\
\text { non faecal N losses with WWG than with FM. } \\
\text { Lower faecal P losses than with FM. Same } \\
\text { protein, fat and phosphorus body composition } \\
\text { with WWG as with FM. }\end{array}$} & \multirow[t]{2}{*}{ [40] } \\
\hline & & 58.3 & 32.8 & No & 34.7 & No & 55.6 & & \\
\hline \multirow[t]{2}{*}{ Rainbow trout } & \multirow[t]{2}{*}{60} & 50 & 23.7 & No & 30.3 & 1.40 & 50 & \multirow{2}{*}{$\begin{array}{l}\text { Similar growth with FM diet and when FM is } \\
\text { totally replaced with a mixture of WWG and } \\
\text { crystalline amino acids. }\end{array}$} & \multirow[t]{2}{*}{ [9] } \\
\hline & & 0 & 77.0 & No & 31.6 & 2.50 & 50 & & \\
\hline \multirow[t]{2}{*}{ Rainbow trout } & \multirow[t]{2}{*}{65} & 72 & 0 & $\mathrm{SBM}^{3}: 23$ & 45.5 & No & 23.7 & \multirow{2}{*}{$\begin{array}{l}\text { Better growth and feed efficiency with WWG and } \\
0.29 \% \text { Lys than with the FM diet. Greater apparent net } \\
\text { protein utilisation and protein efficiency ratio. No } \\
\text { modification of protein and lipid content in carcasses. }\end{array}$} & \multirow[t]{2}{*}{ [20] } \\
\hline & & 31 & 53 & $W^{3}: 5 S B M: 6 ; W M: 5$ & 46.6 & 0.29 & 23.7 & & \\
\hline \multirow[t]{3}{*}{ European sea bass } & \multirow[t]{3}{*}{96} & 100 & 0 & No & 49.9 & No & 23.9 & \multirow{3}{*}{$\begin{array}{l}\text { Weight gain slightly lower in fish fed with 70\% WWG } \\
\text { and no change in feed conversion ratio. Same faecal, } \\
\text { retention and metabolic losses of N. }\end{array}$} & \multirow[t]{3}{*}{ [10] } \\
\hline & & 50 & 50 & No & 49.7 & 0.20 & 23.9 & & \\
\hline & & 30 & 70 & No & 49.9 & 0.80 & 23.9 & & \\
\hline \multirow[t]{2}{*}{ Sea bream } & \multirow[t]{2}{*}{85} & 95 & 0 & No & 44.8 & No & 41.6 & \multirow{2}{*}{$\begin{array}{l}\text { Significantly higher weight gain and feed efficiency } \\
\text { with WWG than with FM. Same productive protein } \\
\text { value and higher energy retention value with WWG } \\
\text { than with FM. Same protein, lipid, energy, and } \\
\text { phosphorus body composition with WWG as with FM. }\end{array}$} & \multirow[t]{2}{*}{ [39] } \\
\hline & & 0 & 88 & No & 45.1 & 2.10 & 41.2 & & \\
\hline
\end{tabular}

${ }^{1}$ CP: Crude Protein; ${ }^{2}$ PP: Plant Protein; ${ }^{3}$ SBM: Soybean Meal; WM: Wheat Middlings. 
Table 4 Effects of Vital Wheat Gluten (VWG) or other Plant Protein (PP) sources on growth performance of different fish species

\begin{tabular}{|c|c|c|c|c|c|c|c|c|}
\hline Species & Duration, d. & $\begin{array}{l}\text { Tested } \\
\text { Protein }^{1} \\
\end{array}$ & Protein, $\% C P^{2}$ & $\% \mathrm{CP}$ in diet & $\begin{array}{l}\text { Lys. Supp. } \\
\text { (\% diet) }\end{array}$ & $\mathrm{iBW}^{3}(\mathrm{~g})$ & Main results & Reference \\
\hline \multirow[t]{6}{*}{ Nile tilapia } & \multirow[t]{6}{*}{49} & FM & 88 & 32.5 & No & 56.4 & \multirow{6}{*}{$\begin{array}{l}\text { Highest feed efficiency and growth for FM, } \\
\text { WWG, and SBE. No significant modifications } \\
\text { in body composition for dry matter, protein, } \\
\text { fat, P, and energy. Highest ash body } \\
\text { content for DWD, SCP, and FM. }\end{array}$} & \multirow[t]{6}{*}{ [40] } \\
\hline & & WWG & 32.8 & 34.7 & No & 55.6 & & \\
\hline & & SBM & 23.9 & 30.5 & No & 55.6 & & \\
\hline & & SBE & 34.2 & 35.7 & No & 54.3 & & \\
\hline & & DW & 18.5 & 27.5 & No & 60.2 & & \\
\hline & & SCP & 20.9 & 29.1 & No & 54.8 & & \\
\hline \multirow[t]{4}{*}{ Sea bream } & \multirow[t]{4}{*}{85} & FM & 95 & 44.8 & No & 41.6 & \multirow{4}{*}{$\begin{array}{l}\text { Better weight gain with WWG, before FM } \\
\text { and before SPC and CGM. Same productive } \\
\text { protein value and higher energy retention } \\
\text { value with WWG as with FM. }\end{array}$} & \multirow[t]{4}{*}{ [39] } \\
\hline & & WWG & 88 & 45.1 & 2.10 & 41.2 & & \\
\hline & & SPC & 98 & 43.9 & No & 41.7 & & \\
\hline & & CGM & 88 & 45.8 & 2.10 & 39.2 & & \\
\hline
\end{tabular}

${ }^{1}$ CP: Crude Protein; ${ }^{2}$ FM: Fish Meal; VWG: Vital Wheat Gluten; SBM: Soybean Meal; SBE: Soybean Extract; DW: Duckweed; SCP: single-cell protein; SPC: Soy Protein Concentrate; CGM: Corn Gluten Meal; ${ }^{3}$ iBW: initial Body Weight.

positive antioxidant effect by enhancing the glutathione metabolism in gilthead sea bream [58]. It also modulates immune system, notably by decreasing complement levels in blood [58]. The effects of high dietary concentrations of soybean proteins on the non-specific immune response are also reported in rainbow trout with inconsistent results $[59,60]$. Gut and liver morphology is also modified when replacing FM with up to $50 \%$ PP in gilthead sea bream and rainbow trout $[58,61]$. All these results are complex and not always consistent. Furthermore, quantifying the relative effect of each PP in order to balance a diet high in PP remains difficult since current knowledge is still limited. Further investigations are needed to establish the effects of each PP and their interrelationships.

In this field, there is evidence in terrestrial animals showing that VWG is an interesting source of proteins for maintaining gut health and stimulating the immune system. In piglets, weaning is a highly stressful period characterised by an immediate and transient drop in feed intake, by modifications of various aspects of small intestine morphology and function (villi atrophy, drop in enzyme activity, local inflammation); and may lead to intestinal disorders and diarrhoea [62]. As for fish feed, replacement of animal proteins is investigated in starter feed. Replacing 6\% FM or 6\% Whey Protein Concentrate, considered as good protein sources for piglets, with 6\% SBM or Rice Protein Concentrate results in diminishing villi height [63]. On the contrary, replacing 10\% FM with 9.5\% VWG does not negatively affect villi height, which is even numerically higher with VWG than with FM, with a similar feed intake [64]. These authors conclude that the positive effect of VWG on villi height may be attributed to the high amount of glutamine rather than feed intake. In fish, to our knowledge, very few data are available. Nevertheless, the replacement of 15\% FM by SBM leads to pathological changes in the distal intestine of Atlantic salmon while the replacement of $35 \%$ of FM by
VWG does not result in such damages, , probably related to the absence of ANF and to the high content of glutamine in VWG [8]. Furthermore, replacing 5\% SPC with 5\% Hydrolysed Wheat Gluten (HWG) results in improved performance, gut structure and activity, and immune response in juvenile hybrid sturgeons $[28,29]$. The results obtained with 3 to $5 \%$ HWG are similar to the results obtained when adding $1 \%$ glutamine, so that the authors conclude the effect of HWG on health may be due to the high amount of glutamine. The determination of the glutamine effect in native $v s$ hydrolysed Wheat Gluten has not been investigated in fish and leads to inconsistent results in terrestrial animals, with either difference [64] or not [65]. These data suggest VWG can be a PP source limiting the negative impact on fish health when fed with high PP levels.

\section{Lipid metabolism}

Lipid metabolism may be affected when fish are fed with high PP levels. It is important to take into account lipid metabolism in farmed fish since these factors may affect flesh quality. Adding high levels of PP sources in diets modulates lipid metabolism pathways when comparing to FM diets in several species [66]. Plasma cholesterol decreases in European sea bass (replacement up to 95\% FM [67], in gilthead sea bream (replacement up to 100\% FM; [58]) and in whole fillet of large rainbow trout (replacement up to $100 \% \mathrm{FM}$; [68]) when fish are fed with high amount of a blend composed of several PP sources. Also, a modification of fatty acid desaturation or elongation, with a strong increase of PUFA n- 6 and a slight decrease of PUFA n-3 in fillets of large rainbow trout as in muscle of European sea bass are described $[68,69]$. Recently, a different lipid distribution between dorsal muscle and liver was observed when European sea bass is fed with up to $70 \% \mathrm{CP}$ with different PP sources without modifying overall adiposity and mesenteric fat [69]. 
Several mechanisms are proposed to explain such effects. First, there is evidence from different animal models indicating the effect of varying the dietary protein source on fat content could depend on changes in the activity of liver lipogenic enzymes. In rats, the differential effect of dietary proteins on plasma cholesterol level is mainly associated with sulfur amino acids including in the protein [70]. More generally, differences in the amino acid composition of diets including plant $v s$ animal proteins have been mentioned as a major factor in the mechanisms modulating de novo fatty acid synthesis [71]. Secondly, an increased PP source in diets is related to increased starch level so that both effects are confounded. A significant correlation between starch, glycaemia, and the activities of such lipogenic effects are already underlined in sea bream [72]. Thirdly, some ANF like isoflavones contained in soy proteins are shown to affect lipid metabolism and lower plasma cholesterol [73].

The effects of PP sources on lipid metabolism seem to be various, regarding the properties of PP source itself, i.e. the amino acid composition, the content of starch and the ANF. A dietary plant-protein substitution affects hepatic metabolism of rainbow trout but that the metabolic effects of PP replacement in fish feed varied with PP source [74]. In the different experiments previously cited, a blend of several PP sources was tested so that it is not possible to conclude which PP is the most involved compared to the others on the modulation of lipid metabolism and to define potential interactions between PP. Interestingly, when compared extruded or pelleted wheat gluten-based diets in European sea bass, no clear postprandial patterns of plasma cholesterol were discernible and cholesterol with VWG diet was only slightly, but not significantly, lower than plasma cholesterol of fish fed with FM diet [38]. Effects of up to 70\% VWG as replacement of FM, a blend of VWG and pea, and a blend of VWG and SBM have been compared [69]. The plasma cholesterol and triacylglycerol concentrations were not significantly modified by VWG or VWG and pea but decreased with the blend of VWG and SBM, suggesting soy proteins play a major role in decreasing cholesterol and triacylglycerols in blood. However, VWG diets as soy-protein diets were found to decrease PUFA (n-3) and to increase PUFA (n-6) in muscle. These results underline PP have probably different routes of action on lipid metabolism.

\section{Conclusion}

The use of VWG in fish feed offers different opportunities in term of technological properties. Furthermore, because of its nutritional properties, the replacement of a large part of FM with VWG is well-established and does not adversely affect feed intake, growth, feed and nutrient efficiency, and overall composition of different species of fish. Nowadays, research is refining and is moving towards understanding the impact of PP-based diets on fish health and metabolism. The knowledge of the pattern of each PP has to be completed by the knowledge of the effects of several PP in a same diet, their possible interactions, in order to optimise the formulation and the choice of ingredients. Indeed, using the correct mixture of PP provides not only the possibility of limiting damages, but also offers an interesting possibility to enhance antioxidant status and to modulate the immune response. In this way, the use of VWG in a diet containing high amount of PP may contribute to secure diets and to preserve health of fish.

\section{Competing interests}

The authors declare that they have no competing interests.

\section{Authors' contributions}

$E A B, A F, A W$ and $F R$ participated in the sequence alignment and drafted the manuscript. All authors read and approved the final manuscript.

Received: 2 September 2013 Accepted: 6 November 2013

Published: 16 November 2013

\section{References}

1. Olsen RL, Hasan MR: A limited supply of fishmeal: Impact on future increases in global aquaculture production. Trends in Food Sci Technol 2012, 27:120-128.

2. Tacon AGJ, Hasan MR, Metian M: Demand and supply of feed ingredients for farmed fish and crustaceans: trends and prospects. FAO Fisheries Aquaculture Tech Paper 2011, 564:87. Rome.

3. Mambrini M, Roem AJ, Carvèdi JP, Lallès JP, Kaushik S: Effects of replacing fish meal with soy protein concentrate and of DL-methionine supplementation in high-energy, extruded diets on the growth and nutrien utilization of rainbow trout, Onchorhynchus mykiss. J Anim Sci 1999, 77:2990-2999.

4. Carter CG, Hauler RC: Fish meal replacement by plant meals in extruded feeds for Atlantic salmon, Salmo salar L. Aquaculture 2000, 185:299-311.

5. Bransden MP, Carter CG, Nowak BF: Effects of dietary protein source on growth, immune function, blood chemistry and disease resistance of Atlantic salmon (Salmo salar L.) parr. Anim Sci 2001, 73:105-113.

6. Zhang Y, Overland M, Shearer KD, Sorensen M, Mydland LT, Storebakken T: Optimizing plant protein combinations in fish meal-free diets for rainbow trout (Onchorhynchus mykiss) by a mixture model. Aquaculture 2012, 360-361:25-36.

7. Tusche K, Arning S, Wuertz S, Susenbeth A, Schulz C: Wheat gluten and potato protein concentrate - Promising protein sources for organic farming of rainbow trout (Oncorhynchus mykiss). Aquaculture 2012, 344-349:120-125.

8. Storebakken T, Shearer KD, Baeverfjord G: Digestibility of macronutrients, energy and amino acids, ansorption of elements and absence of intestinal enteritis in Atlantic salmon, Salmo salar, fed diets with wheat gluten. Aquaculture 2000, 184:115-132.

9. Rodehutscord M, Mandel S, Pack M, Jabobs S, Pfeffer E: Free amino acids can replace protein-bound amino acids in test diest for studies in rainbow trout (Oncorhynchus mykiss). J Nutr 1995, 125:956-963.

10. Tibaldi E, Tulli F, Piccolo G, Guala S: Wheat gluten as a partial substitute for fish meal protein in sea bass (D. labrax) diets. Ital J Anim Sci 2003, 2:613-615.

11. Day L, Augustin MA, Batey IL, Wrigley CW: Wheat-gluten uses and industry needs. Trends Food Sci Technol 2006, 17:82-90.

12. Wieser H: Chemistry of gluten proteins. Food Microbiol 2007, 24(2):115-119.

13. Wilson RP: Utilization of dietary carbohydrate by fish. Aquaculture 1994, 124(1-4):67-80.

14. Stone DAJ: Dietary Carbohydrate Utilization by Fish. Rev Fisheries Sci 2003 , 11(4):337-369.

15. Draganovic V, GootbVan der AJ, Boomb R, Jonkersa J: Assessment of the effects of fish meal, wheat gluten, soy protein concentrate and feed moisture on extruder system parameters and the technical quality of fish feed. Anim Feed Sci d Technol 2011, 165:238-250. 
16. Kaushik SJ, Seiliez I: Protein and amino acid nutrition and metabolism in fish: current knowledge and future needs. Aquacult Res 2010, 41(3):322-332

17. NRC: Nutrient requirements of fish and shrimp. Washington: The National Academies Press; 2011

18. Wilson RP, Cowey CB: Amino acid composition of whole body tissue of rainbow trout and Atlantic salmon. Aquaculture 1985, 48(3-4):373-376.

19. Pfeffer $E$, Kinsinger $S$, Rodehutscord M: Influence of the proportion of poultry slaughter by-products and of untreated or hydrothermically treated legume seeds in diets for rainbow trout (Onchorhyncus mykiss) on apparent digestibilities of their energy and organic components. Aquacult Nutr 1995, 1:111-117.

20. Davies SJ, Morris PC, Baker RTM: Partial substitution of fish meal and full-fat soya bean meal with wheat gluten and influence of lysine supplementation in diets for rainbow trout, Oncorhyncus mykiss (Walbaum). Aquacult Res 1997, 28:317-328.

21. Li P, Mai K, Trushenski J, Wu G: New developments in fish amino acid nutrition: towards functional and environmentally oriented aquafeeds. Amino Acids 2009, 37(1):43-53.

22. Nicklin $P$, Bergman $P$, Zhang $B$, Triantafellow $E$, Wang $H$, Nyfeler $B$, Yang $H_{\text {, }}$ Hild M, Kung C, Wilson C, Myer VE, MacKeigan JP, Porter JA, Wang YK, Cantley LC, Finan PM, Murphy LO: Bidirectional transport of amino acids regulates mTOR and Autophagy. Cell 2009, 136:521-534.

23. Seiliez I, Gabillard JC, Skiba-Cassy S, Garcia-Serrana D, Gutie'rrez J, Kaushik SJ, Panserat S, Tesseraud S: An in vivo and in vitro assessment of TOR signaling cascade in rainbow trout (Oncorhynchus mykiss). Am J Regul Integ Comp Physiol 2008, 295:R329-R335.

24. Cleveland BM, Weber GM: Effects of insulin-like growth factor-I, insulin, and leucine on protein turnover and ubiquitin ligase expression in rainbow trout primary myocytes. Am J Regul Integ Comp Physiol 2010, 298:R341-R350.

25. Verlhac-Trichet V: Nutrition and immunity: an update. Aquacult Res 2010, 41:356-372

26. Pohlenz C, Buentello AMB, GatlinlII DM: Free dietary glutamine improves intestinal morphology and increases enterocyte migration rates, but has limited effects on plasma amino acid profile and growth performance of channel catfish Ictalurus punctatus. Aquaculture 2012, 370-371:32-39.

27. Cheng Z, Gatlin DM III, Buentello A: Dietary supplementation of arginine and/or glutamine influences growth performance, immune responses and intestinal morphology of hybrid striped bass (Morone chrysops $\times$ Morone saxatilis). Aquaculture 2012, 362-363:39-43.

28. Qiyou X, Qing Z, Hong X, Chang'an W, Dajiang S: Dietary glutamine improves growth performance and intestinal digestion/absorption ability in young hybrid sturgeon. J Appl Ichthyol 2011, 27:721-726.

29. Zhu Q, Xu QY, Wang CA, Sun DJ: Dietary glutamine supplementation improves tissue antioxidant status and serum non-specific immunity of juvenile hybrid sturgeon. J Appl Ichthyol 2011, 27:715-720.

30. Wu G: Intestinal mucosal amino acid catabolism. J Nutr 1998, 128(8):1249-1252.

31. Wu G, Bazera FW, Davisa TA, Jaegere LA, Johnsone GA, Kima SW, Knabea DA, Meiningerc CJ, Spencera TE, Yina YL: Important roles for the arginine family of amino acids in swine nutrition and production. Livest,Sci 2007, 112(1-2):8-22.

32. Yan $L$, Qiu-Zhou X: Dietary glutamine supplementation improves structure and function of intestine of juvenile Jian carp (Cyprinus carpio var. Jian). Aquaculture 2006, 256:389-394.

33. Pfeffer $\mathrm{E}, \mathrm{Al}$-Sabty H, Haverkamp R: Studies on lysine requirements of rainbow trout (Oncorhynchus mykiss) fed wheat gluten as only source of dietary protein. J Anim Physiol Anim Nutr 1992, 67(1-5):74-82.

34. Sugiura SH, Dong FM, Rathbone CK, Hardy RW: Apparent protein digestibility and mineral availabilities in various feed ingredients for salmonid feeds. Aquaculture 1997, 159:177-202.

35. Lemos D, Lawrence AL, Siccardi AJ III: Prediction of apparent protein digestibility of ingredients and diets by in vitro $\mathrm{pH}$-stat degree of protein hydrolysis with species-specific enzymes for juvenile Pacific white shrimp Litopenaeus vannamei. Aquaculture 2009, 295(1-2):89-98.

36. Tibbetts SM, Milley JE, Lall SP: Apparent protein and energy digestibility of common and alternative feed ingredients by Atlantic cod, Gadus morhua. Aquaculture 2006, 261:1314-1327.

37. Allan GL, Parkinson S, Booth MA, Booth MA, Stone DAJ, Rowland SJ, Frances J, Warner-Smith R: Replacement of fish meal in diets for Australian silver perch, Bidyanus bydianus: I. digestibility of alternative ingredients. Aquaculture 2000, 186:293-310.
38. Robaina L, Corraze G, Aguirre P, Blanc D, Melcion JP, Kaushik SK: Digestibility, postprandial ammonia excretion and selected plasma metabolites in European sea bass Dicentrarchus labrax/ fed pelleted or extruded diets with or without wheat gluten. Aquaculture 1999, 179:45-56.

39. Kissil GW, Lupatsch I: Successful replacement of fishmeal by plant proteins in diets for the gilthead seabream, Sparus aurata L. Israeli J Aquacult 2004, 56(3):188-199.

40. Schneider O, Amirkolaie AK, Vera-Cartas J, Eding EH, Schrama JW, Verreth JAJ: Digestibility, faeces recovery, and related carbon, nitrogen and phosphorus balances of five feed ingredients evaluated as fishmeal alternatives in Nile tilapia, Oreochromis niloticus L. Aquacult Res 2004, 35:1370-1379.

41. Refstie S, Storebakken T, Roem AJ: Feed consumption and conversion in Atlantic salmon (Salmo salar) fed diets with fish meal, extracted soybean meal or soybean meal with reduced content of oligosaccharides, trypsin inhibitors, lectins and soya antigens. Aquaculture 1998, 162(3-4):301-312.

42. Storebakken T, Shearer KD, Roem AJ: Availability of protein, phosphorus and other elements in fish meal, soy protein concentrate and phytate-treated soy protein concentrate based diets to Atlantic salmon, Salmo salar. Aquaculture 1998, 161:365-379.

43. Denstadli V, Skrede A, Krogdahl A, Sahlstrømd S, Storebakken T: Feed intake, growth, feed conversion, digestibility, enzyme activities and intestinal structure in Atlantic salmon (Salmo salar L.) fed graded levels of phytic acid. Aquaculture 2006, 256(1-4):365-376.

44. Fredlund $K$, Isaksson M, Rossander-Hulthénc L, Almgrena A, Sandberga AS: Absorption of zinc and retention of calcium: dose-dependent inhibition by phytate. J Trace Elems Med Biol 2006, 20(1):49-57.

45. Gatlin DM III, Barrows FT, Brown P, Dabrowski K, Gaylord TG, Hardy RW Herman E, Hu G, Krogdahl A, Nelson R, Overturf K, Rust M, Sealey W, Skonberg D, Souza EJ, Stone D, Wilson R, Wurtele E: Expanding the utilization of sustainable plant products in aquafeeds: a review. Aquacult Res 2007, 38(6):551-579.

46. Hilton JW, Atkinson $\mathrm{J}$, Slinger SJ: Effect of increased dietary fiber on the growth of rainbow trout (Salmo gairdneri). J Can Sci Halieutiques Aquat 1983, 40(1):81-85.

47. Shiau SY, Kwok CC, Chen CJ, Hong HT, Hsieh HB: Effects of dietary fibre on the intestinal absorption of dextrin, blood sugar level and growth of tilapia, Oreochromis niloticm × O. aureus. J Fish Biol 1989, 34(6):929-935.

48. Hossain MA, Focken U, Becker K: Evaluation of an unconventional legume seed, Sesbania aculeata, as a dietary protein source for common carp, Cyprinus carpio L. Aquaculture 2001, 198(1-2):129-140.

49. Refstie S, Svihusb B, Shearerc KD, Storebakken T: Nutrient digestibility in Atlantic salmon and broiler chickens related to viscosity and non-starch polysaccharide content in different soyabean products. Anim Feed Sci Technol 1999, 79(4):331-345

50. Dias J, Huelvan C, Dinis M, Metailler R: Influence of dietary bulk agents (silica, cellulose and a natural zeolite) on protein digestibility, growth, feed intake and feed transit time in European seabass (Dicentrarchus labrax) juveniles. Aquat Living Resour 1998, 11(4):219-226.

51. Krogdahl A, Penn M, Thorsen J, Refsie S, Bakke AM: Important antinutrients in plant feedstuffs for aquaculture: an update on recent findings regarding responses in salmonids. Aquacult Res 2010, 41:333-344.

52. McKellep Bakke AM, Penn M, Mora Salas P, Refstie S, Sperstad S, Landsverk T, Ringo E, Krogdahl A: Effects of dietary soyabean meal, inulin and oxytetracycline on intestinal microbiota and epithelial cell stress, apoptosis and proliferation in the teleost Atlantic salmon (Salmo salar L.). Brit J Nutr 2007, 97:699-713.

53. Dimitroglou A, Reynolds P, Ravnoy B, Johnsen F, Sweetman JW, Johansen J, Davies SJ: The effect of Mannan Oligosaccharide supplementation on Atlantic salmon smolts (Salmo salar L.) fed diets with high levels of plant proteins. J Aquacult Res Dev 2011, S1:011.

54. Penn MH, Bendiksen EA, Campbell P, Krogdahl A: High level of dietary pea protein concentrate induces enteropathy in Atlantic salmon (Salmo salar L.). Aquaculture 2011, 310:267-273.

55. Skonberg D, Hardy RW, Barrows RT, Dong FM: Color and flavour analyses from farm-raised rainbow trout (Onchorhyncus mykiss) fed low-phosphorus feeds containing corn or wheat gluten. Aquaculture 1998, 166:269-277.

56. Molina-Poveda C, Morales ME: Use of a mixture of barley-based fermented grains and wheat gluten as an alternative protein source in practical diets for Litopenaeus vannamei (Boone). Aquacult Res 2004, 35:1158-1165.

57. Santigosa E, Sánchez J, Medale F, Kaushik SK, Pérez-Sánchez J, Gallardo MA: Modifications of digestive enzymes in trout (Oncorhynchus mykiss) and 
sea bream (Sparus aurata) in response to dietary fish meal replacement by plant protein sources. Aquaculture 2008, 282:68-74.

58. Sitjà-Bobadilla A, Peña-Llopisa S, Gómez-Requenia P, Medale F, Kaushik SK, Pérez-Sánchez J: Effect of fish meal replacement by plant protein sources on non-specific defence mechanisms and oxidative stress in gilthead sea bream (Sparus aurata). Aquaculture 2005, 249:387-400

59. Rumsey GL, Siwicki AK, Anderson DP, Bowser PR: Effect of soybean protein on serological response, non-specific defense mechanisms, growth, and protein utilization in rainbow trout. Vet Immunol Immunopathol 1994, 41:323-339.

60. Burrells C, Williams PD, Southgate PJ, Crampton VO: Immunological, physiological and pathological responses of rainbow trout (Oncorhynchus mykiss) to increasing dietary concentrations of soybean proteins. Vet Immunol Immunopathol 1999, 72:277-288.

61. Barrows FT, Gaylord TG, Stone DAJ, Smith CE: Effect of protein source and nutrient density on growth efficiency, histology and plasma amino acid concentration of rainbow trout (Oncorhynchus mykiss Walbaum). Aquacult Res 2007, 38:1747-1758.

62. Lallès JP, Boudry G, Favier C, Le Floch N, Luron I, Montagne L, Oswald IP, Pié S, Piel C, Sève B: Gut function and dysfunction in young pigs: physiology. Anim Res 2004, 53:301-316.

63. Yun JH, Kwon IK, Lohakare JD, Choi JY, Yong JS, Zheng J, Cho WT, Chae BJ: Comparative efficacy of plant and animal protein sources on the growth performance, nutrient digestibility, morphology and caecal microbiology of early-weaned Pigs. Asian-Aust J Anim Sci 2005, 18:1285-1293.

64. Blasco M, Fondevila M, Guada JA: Inclusion of wheat gluten as a protein source in diets for weaned pigs. Anim Res 2005, 54:297-306.

65. Vente-Spreeuwenberg MAM, Verdonk JMA, Koninkx JFJG, Beynen AC, Verstegen MW: A. Dietary protein hydrolysates vs. the intact proteins do not enhance mucosal integrity and growth performance in weaned piglets. Livest Prod Sci 2004, 85:151-164.

66. Piccolo G, Centoducati G, Bovera F, Marrone R, Nizza A: Effects of mannan oligosaccharides and inulin on sharpsnout seabream (Diplodus puntazzo) in the context of partial fish substitution by soybean meal. Ital J Anim Sci 2013, 12(1):133-138.

67. Kaushik SJ, Covès D, Dutto G, Blanc D: Almost total replacement of fish meal by plant protein sources in the diet of a marine teleost, the European seabass, Dicentrarchus labrax. Aquaculture 2004, 230:391-404.

68. De Francesco M, Parisi G, Medale F, Lupia P, Kaushik SK, Polia BM: Effect of long-term feeding with a plant protein mixture based diet on growth and body/fillet quality traits of large rainbow trout (Oncorhynchus mykiss). Aquaculture 2004, 236:413-429.

69. Messina M, Piccolo G, Tulli F, Messina CM, Cardinaletti G, Tibaldi E: Lipid composition and metabolism of European sea bass (Dicentrarchus labrax L.) fed diets containing wheat gluten and legume meals as substitutes for fish meal. Aquaculture 2013, 376-379:6-14.

70. Sugiyama K, Ohkawa S, Muramatsu K: Relationship between amino acid composition of diet and plasma cholesterol level in growing rats fed a high cholesterol diet. J Nutr Sci vitaminol 1986, 32:413-422.

71. Dias J, Alvarez MJ, Arzel J, Corraze G, Diez A, Bautist JM, Kaushik SJ: Dietary protein source affects lipid metabolism in the European seabass (Dicentrarchus labrax). Comp Biochem Physiol 2005, 142:19-31.

72. Meton I, Mediavilla D, Caseras A, Canto E, Fernandez F, Baanante IV: Effect of diet composition and ration size on key enzyme activities of glycolysis-gluconeogenesis, the pentose phosphate pathway and amino acid metabolism in liver of gilthead sea bream (Sparus aurata). Bi J Nutr 1999, 82:223-232.

73. Kaushik SJ, Cravedi JP, Lalles JP, Sumpter J, Fauconneau B, Laroche M: Partial or total replacement of fish meal by soybean protein on growth, protein utilization, potential estrogenic or antigenic effects, cholesterolemia and flesh quality in rainbow trout, Oncorhynchus mykiss. Aquaculture 1995, 133:257-274.

74. Vilhelmsson OT, Martin SAM, Medale F, Kaushik SJ, Houlihan DF: Dietary plant-protein substitution affects hepatic metabolism in rainbow trout (Oncorhynchus mykiss). Br J Nutr 2004, 92:71-80.

\section{Submit your next manuscript to BioMed Central and take full advantage of:}

- Convenient online submission

- Thorough peer review

- No space constraints or color figure charges

- Immediate publication on acceptance

- Inclusion in PubMed, CAS, Scopus and Google Scholar

- Research which is freely available for redistribution 